\title{
Determination of free ammonium in plant tissue
}

\author{
I. Novozamsky and V. J. G. Houba \\ Department of Soils and Fertilizers, Agricultural University, Wageningen, the \\ Netherlands
}

Accepted: 8 December 1976

Key words: Free ammonium, plant tissue, potentiometry, gas diffusion electrode

\section{Summary}

A gas diffusion ammonia electrode was tested as a means of determining free ammonium in plant tissue. The possible interferences of glutamine and asparagine were tested and were found not to be a serious obstacle. Furthermore the importance of the pretreatment of plant material was stressed.

\section{Introduction}

Nitrogen contained in free ammonium constitutes only a minor portion of the total amount of nitrogen present in plants. Nevertheless, in view of the key role played by ammonium in the production of amino acids and proteins, knowledge of the content of free ammonium in plants may be desirable, the more so since a high content of ammonium can be harmful to a plant.

Different procedures have been used to extract free ammonium from plant tissue. Fresh, dried and lyophilized plant material has been extracted with water or alcohol, with or without a pretreatment with ether (Routchenko, 1967; Breteler, 1972).

For the determination itself use has been made of colorimetric methods (Nessler reagent or indophenol blue) (Yuen \& Pollard, 1952), or $\mathrm{NH}_{3}$ has been distilled over from the extract buffered at a relatively low $\mathrm{pH}$ value by, for example, a borate buffer (Breteler, 1972). A separation of ammonium from organically bound nitrogen by means of a cation exchange resin was also proposed (Routchenko, 1967; Henderlong \& Schmidt, 1966).

Unfortunately, in plant extracts a determination of ammonium is bound to take place in the presence of relatively high concentrations of amino acids, hydrolysable at high $\mathrm{pH}$ values. Distillation procedures and also the colorimetric procedures in which samples are exposed for prolonged periods to high $\mathrm{pH}$ values should be considered with caution.

The introduction of the gas diffusion electrode (Orion) for the determination of ammonium created a new possibility to circumvent this problem. The electrode seems able to sense dissolved $\mathrm{NH}_{3}$ at very low concentrations in a rather broad 
pH range. Only amines with low molecular weights were reported to interfere (Dewolfs et al., 1975).

The purpose of the present study was to test the performance of the electrode in the presence of high concentrations of amino acids and to examine the applicability of the electrode for the determination of $\mathrm{NH}_{4}+$ in plant extracts.

\section{Material and methods}

The Orion gas diffusion electrode (Model 95-10) was used as an ammonia sensor. Measurements were performed with a $\mathrm{mV}$ meter with a sensitivity of $\pm 1 \mathrm{mV}$.

For $\mathrm{pH}$ measurements a Radiometer $\mathrm{pH}$ meter (type PHM 64) with a variable iso-pH point was used. If necessary, the ionic strength of a solution was estimated by means of a conductivity measurement.

All chemicals used were of analytical grade; the nitrogen contents of the amino acids were checked by means of total-N analyses.

For analysis, normally dried plant material of different origin was used. The influence of a pretreatment was checked by drying the plant material at 70 and $45^{\circ} \mathrm{C}$ and by freeze-drying. For this purpose, maize plants were grown on a Hoagland solution for a period of 3 weeks and subsequently transferred to a solution containing 10 meq $\mathrm{NH}_{4} \mathrm{Cl}$ per liter, on which they were kept for a week. The $\mathrm{pH}$ of this latter solution was kept nearly constant by addition of $\mathrm{NH}_{4} \mathrm{OH}$. This plant material was divided into leaves and stems.

\section{Procedure}

$2-4 \mathrm{~g}$ of plant material were extracted with $100 \mathrm{ml} \mathrm{H}_{2} \mathrm{O}$ by shaking for 2 hours at room temperature. After filtration a 5-ml aliquot was taken for the measurement, the $\mathrm{pH}$ was raised by adding $0.1 \mathrm{ml}$ of a $10 \mathrm{M} \mathrm{NaOH}$ solution or $5.0 \mathrm{ml}$ of a borate solution buffered at $\mathrm{pH} 10.70$ (prepared according to Breteler, 1972).

Standard solutions with a concentration of $10^{-\mathrm{s}}$ to $10^{-2} M$ total ammonium were prepared from $\left(\mathrm{NH}_{4}\right)_{2} \mathrm{SO}_{4}$ p.a. Here again, either a borate buffer or $\mathrm{NaOH}$ was used to increase the $\mathrm{pH}$.

On account of the fact that in the samples at the respective $\mathrm{pH}$ levels only that part of the ammonium is sensed which is present as $\mathrm{NH}_{3}$, the $\mathrm{pH}$ values also have to be determined. The ammonia contents are calculated from the reaction

$$
\mathrm{NH}_{4}+\gtrless \mathrm{NH}_{3}+\mathrm{H}^{+} \quad \mathrm{K}=10^{-8.25}(\mathrm{I}=0.0) \text {. }
$$

The value of $\mathrm{K}$ is corrected for the ionic strength of the measured solutions and standards with the use of the Davies formulae (Davies, 1962).

For comparison, other aliquots of the same extracts were subjected to other distillation methods, namely the one proposed by Breteler (1972) and the one in which $\mathrm{NaOH}$ is added, as used in our own laboratory (van Schouwenburg \& Walinga, 1975). 


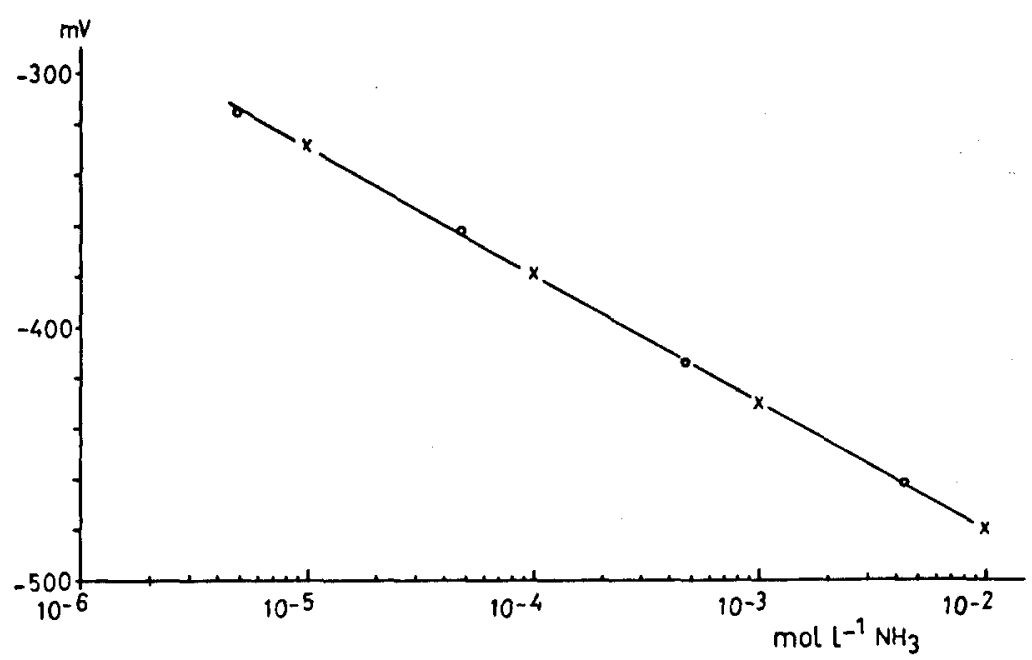

Fig. 1. Response of the ammonia electrode to variations in the ammonium concentration of standard solutions.

$\times 5 \mathrm{ml}$ solution $+0.1 \mathrm{ml} 10 M \mathrm{NaOH}$ (pH of these solutions higher than 12);

$\bigcirc 5 \mathrm{ml}$ solution $+5 \mathrm{ml}$ buffer solution $\left(\mathrm{pH}\right.$ variable; $\mathrm{NH}_{3}$ concentration calculated from $\mathrm{pH}$ and appropriate equilibrium constant).

\section{Results and discussion}

The behaviour of the electrode was completely in agreement with the data reported by others (Dewolfs et al., 1975; Anon., 1972). In Fig. 1 a response line of the electrode is given for solutions with different concentrations of ammonium obtained by varying the total ammonium concentration or by varying the $\mathrm{pH}$. It should be pointed out that the measurement at the lower $\mathrm{pH}$ values were less reproducible because of the necessity of a second measurement that has to be carried out $(\mathrm{pH})$.

As a possible source of error in the determination, the presence of easily hydrolysable asparagine and glutamine should be considered. To check this possibility, measurements were made at different levels of ammonium in solution to which high concentrations of glutamine and asparagine had been added. The measurements were made at different time intervals up to 5 minutes. No influence of either glutamine or asparagine was found when a borax buffer was used to raise the $\mathrm{pH}$ of the solution (final pH varied from 9.4 to 10.7). When $\mathrm{NaOH}$ was used to raise the $\mathrm{pH}$ (12 to 13), hydrolysis of glutamine became measurable especially at a lower level of $\mathrm{NH}_{3}$ (Table 1). Here again asparagine did not interfere. As follows from Table 1 , it is advisable to complete the measurement within 1 minute after the addition of $\mathrm{NaOH}$ to the plant extract.

In Table 2 the results are presented of the determination of ammonium in various plant species with four different procedures. No significant differences were found between the values measured potentiometrically either in solutions containing borax 


\section{DETERMINATION OF FREE AMMONIUM IN PLANT TISSUE}

Table 1. Deviations of the potential of standard solutions $\mathrm{NH}_{3}$ due to the presence of glutamine in different time intervals after addition.

\begin{tabular}{|c|c|c|c|c|c|c|}
\hline \multirow{2}{*}{$\begin{array}{l}\mathrm{NH}_{3}(\mathrm{mmol} / \mathrm{l}) \\
\text { Glutamine }(\mathrm{g} / \mathrm{l})\end{array}$} & \multicolumn{3}{|l|}{0.05} & \multicolumn{3}{|l|}{0.5} \\
\hline & 0.2 & 0.4 & 1 & 0.2 & 0.4 & 1 \\
\hline After 1 minute & 0 & 3 & 8 & 0 & 0 & 1 \\
\hline After 2 minutes & 2 & 5 & 12 & 0 & 0 & 2 \\
\hline After 3 minutes & 3 & 7 & 17 & 0 & 1 & 2 \\
\hline After 5 minutes & 5 & 11 & 22 & 0 & 1 & 4 \\
\hline
\end{tabular}

buffer or $\mathrm{NaOH}$ (lower and higher $\mathrm{pH}$ values, respectively). Values found with the distillation method are substantially higher.

To check the influence of the sample pretreatment two experiments were carried out with maize plants grown especially for this purpose. The results of the ammonium determinations carried out with two potentiometric and two distillation methods are given in Table 3. Again, the values found with the distillation procedures were too high. Furthermore slightly higher values were found in sample solutions made alkaline with $\mathrm{NaOH}$ compared with those treated with borax buffer.

The results are suggesting that a proper pretreatment of plant material, should not be overlooked, and that especially after freeze drying some more ammonium is found particularly in stem material. It is possible that extraction of fresh plant material will lead to still other values. This possibility has not been tested here because of the uncertainties connected with subsampling.

Table 2. Free ammonium in plant material as determined with two procedures (potentiometry and distillation) and two reagents (buffer and $\mathrm{NaOH}$ ) for raising the $\mathrm{pH}$ of the extract.

\begin{tabular}{|c|c|c|c|c|}
\hline \multirow[t]{3}{*}{ Plant material } & \multicolumn{4}{|c|}{$\mathrm{NH}_{4}$ (meq/kg dry matter) } \\
\hline & \multicolumn{2}{|c|}{ potentiometry } & \multicolumn{2}{|c|}{ distillation } \\
\hline & buffer & $\mathrm{NaOH}$ & buffer & $\mathrm{NaOH}$ \\
\hline Oil palm, leaf & 4 & 3 & n.d. & n.d. \\
\hline Rubber, leaf & 8 & 5 & n.d. & n.d. \\
\hline Tea, leaf & 20 & 25 & n.d. & n.d. \\
\hline Buckwheat & 20 & 22 & n.d. & n.d. \\
\hline Freesia & 4 & 6 & 11 & 26 \\
\hline Asparagus, shoot & 1 & 2 & 7 & 21 \\
\hline Cucumber clippings & 8 & 9 & 21 & 77 \\
\hline Green peas & 27 & 22 & 182 & 401 \\
\hline Avocado, leaf & 8 & 4 & 10 & 79 \\
\hline Poplar, leaf & 8 & 7 & 14 & 38 \\
\hline Wheat, grain & 2 & 3 & 15 & 45 \\
\hline
\end{tabular}


Table 3. Ammonium in maize plants after various pre-treatments of the dried plant material as determined with two procedures and two reagents for raising the $\mathrm{pH}$ of the extract.

\begin{tabular}{|c|c|c|c|c|c|}
\hline \multirow[t]{3}{*}{ Plant part } & \multirow[t]{3}{*}{ Pre-treatment } & \multicolumn{4}{|c|}{$\mathrm{NH}_{4}$ (meq/kg dry matter) ${ }^{1}$} \\
\hline & & \multicolumn{2}{|c|}{ potentiometry } & \multicolumn{2}{|c|}{ distillation } \\
\hline & & buffer & $\mathrm{NaOH}$ & buffer & $\mathrm{NaOH}$ \\
\hline \multicolumn{6}{|c|}{ First experiment } \\
\hline Leaf & drying at $70^{\circ} \mathrm{C}$ & 6 & 6 & 24 & 57 \\
\hline Leaf & drying at $45^{\circ} \mathrm{C}$ & 7 & 8 & 27 & 56 \\
\hline Leaf & freeze drying & 7 & 8 & 29 & 66 \\
\hline Stem & drying at $70^{\circ} \mathrm{C}$ & 11 & 15 & 30 & 157 \\
\hline Stem & drying at $45^{\circ} \mathrm{C}$ & 16 & 20 & 33 & 155 \\
\hline Stem & freeze drying & 22 & 29 & 40 & 178 \\
\hline \multicolumn{6}{|c|}{ Second experiment } \\
\hline Leaf & drying at $70^{\circ} \mathrm{C}$ & 16 & 16 & 23 & 一 \\
\hline Leaf & drying at $45^{\circ} \mathrm{C}$ & 13 & 15 & 23 & - \\
\hline Leaf & freeze drying & 19 & 16 & 22 & - \\
\hline Stem & drying at $70^{\circ} \mathrm{C}$ & 80 & 83 & 102 & - \\
\hline Stem & drying at $45^{\circ} \mathrm{C}$ & 75 & 83 & 95 & - \\
\hline Stem & freeze drying & 96 & 102 & 122 & - \\
\hline
\end{tabular}

1 All values given are the means of duplicate determinations.

,

\section{Conclusions}

The gas diffusion ammonia electrode provides a quick and simple way for the determination of free ammonium in plant tissue. Even when measurements are made at high $\mathrm{pH}$ values, the method can be considered to be safe provided that the measurements are made within a few minutes after the addition of base. Coefficients of variation were 12.5 and $7.5 \%$, respectively, for the procedures in which borax buffer and $\mathrm{NaOH}$ were used. The choice whether to measure at higher or lower pH should be considered in any particular case. In one part of our experiments (Table 3) there was a slight tendency towards higher values of ammonia measured at higher $\mathrm{pH}$ values. Because of the lower reproducibility of the measurements at lower $\mathrm{pH}$ values, the determination at higher $\mathrm{pH}$ values should be preferred.

\section{Acknowledgment}

The authors are very much indebted to $\mathrm{Mr} \mathrm{A}$. van de Berg for performing many analyses and to $\mathrm{Mr} \mathrm{J}$. Nelemans for growing the plants.

\section{References}

Anonymous, 1972. Instruction manual ammonia electrode 95-10. Orion Research Inc., USA. Breteler, H., E. M. Wittich \& W. H. Frentz, 1972. De bepaling van vrije asparagine, glutamine 
en ammonium in plantaardig materiaal. Interne Mededeling, Laboratorium voor Landbouwscheikunde, Wageningen, The Netherlands No 4. (In Dutch.)

Davies, C. W., 1962. Ion association. Butterworths, London.

Dewolfs, R., G. Broddin, H. Clysters \& H. Deelstra, 1975. Comparison of two electrodes for the determination of ammonia and nitrogen compounds. $Z$. analyt. Chem. 275: 337-341.

Henderlong, P. R. \& R. R. Schmidt, 1966. Determination of free ammonium and asparagine and glutamine in extracts of plant tissue. Pl. Physiol. 41: 1102-1105.

Routchenko, W., 1967. Appréciations des conditions de la nutrition minérale des plantes basée sur l'analyse des sucs extraits des tissues conducteurs. Annls agron. 18: 361-402.

Schouwenburg, J. Ch. van \& I. Walinga, 1975. Methods of analysis for plant material. Syllabus M.Sc. course, Department of Soils and Fertilizers, Agricultural University, Wageningen. (Mimeographed.)

Yuen, S. H. \& A. G. Pollard, 1952. The determination of nitrogen in agricultural materials by the Nessler reagent. Preparation of the reagent. J. Sci. Fd Agric. 3: 441-447. 